\title{
A REVIEW OF THE INFLUENCE OF DESIGN PARAMETERS ON THE PERFORMANCE OF CONSTRUCTED WETLANDS
}

\author{
Ronnie A. D. Frazer-Williams* \\ Department of Chemistry, Fourah Bay College, University of Sierra Leone, Freetown, Sierra Leone, West Africa
}

\begin{abstract}
This study reviews the influence of wetland design criteria (Kickuth equation, area sizing, first or der kinetics) and operation parameters (hydraulic and influent loading) on pollutant removal (organics, solids, nutrients and coliforms) in both subsurface and surface flow systems. Results showed that despite high removal efficiency reported for most wetlands, residual concentrations for BOD are frequently higher than those predicted based on the 95 percentile first-order Kickuth design equation. Also correlation results indicate that hydraulic and pollutant loading strongly influence wetland performance for organic removal (BOD, COD). In all cases, removal generally decreases as loading increases. Hydraulic loading was not found to correlate with nutrient removal. Overall, it can be concluded that organic removal can be modeled better compared to nutrient in treatment wetlands. Since removal of solids and coliforms are not primarily influenced by the key design parameters, it is expected that they will fit into any design model developed.
\end{abstract}

\section{Keywords}

design criteria, hydraulic loading, removal.

\section{Introduction}

Every year throughout the world millions of industrial CWs have been used in treating wastewater of different characteristics including domestic wastewater ${ }^{1}$, various types of industrial wastewater ${ }^{2-4}$, agricultural wastewater ${ }^{5}$ and storm waters ${ }^{6}$. Recently, they are used as a hybrid VF-HF system, in conjunction with facultative and stabilization ponds to meet tertiary standards in Norway ${ }^{7}$, used in combination with aquatic and soil filters for reclamation of domestic sewage in Chatham County, $\mathrm{USA}^{8}$ and in treatment train together with a filtering and chlorination unit for public water supply in Brazil ${ }^{9}$. In all of these applications, CWs have demonstrated consistent high performance in removing organic matter such as $\mathrm{BOD}, \mathrm{COD}^{10}$; particulate matter (e.g. suspended solids, turbidity); and pathogenic organisms ${ }^{11}$ but less effectively for nutrients ( $\mathrm{N}$ and $\mathrm{P}$ compounds) $)^{1}$ (Table 1 ).

The growing potential of this technology coupled with increasingly strict water quality standards demands the need for the optimization of CWs design so that they are capable of meeting discharge and reuse requirements for diverse applications.

* Corresponding Author's Email: wfdar@yahoo.com
Table 1. Typical average removal efficiency of European constructed wetlands in selected countries

\begin{tabular}{|c|c|c|c|c|c|}
\hline \multirow[t]{2}{*}{ Parameter } & \multicolumn{5}{|c|}{ Average removal efficiency $(\%)$} \\
\hline & Europe $^{\mathrm{a}}$ & $\mathrm{UK}^{\mathrm{b}}$ & $\underset{\mathrm{a}}{\text { Denmark }}$ & $\begin{array}{l}\text { Czech } \\
\text { Republic } \\
\text { c }\end{array}$ & $\begin{array}{l}\text { Poland } \\
\mathrm{c}\end{array}$ \\
\hline $\mathrm{BOD}_{5}$ & 79 & 72 & 80 & 88 & 89 \\
\hline COD & 70 & - & 66 & - & - \\
\hline TSS & - & 80 & 74 & 84 & - \\
\hline $\mathrm{N}_{\text {Tot }}$ & 40 & - & 40 & 51 & - \\
\hline $\mathrm{NH}_{4}-\mathrm{N}$ & 30 & 22 & 34 & - & - \\
\hline $\mathrm{P}_{\text {Tot }}$ & 47 & - & 32 & 42 & - \\
\hline
\end{tabular}

* - data quoted are for Severn Trent $3^{\circ}$ Reed beds in UK which comprises the majority of $\mathrm{CW}$ data in the UK

a-Haberl et al., 1995[12]; ' - Green et al., 1999[13]; cVymazal, 1999[14] 
In view of above, this review examines assumptions inherent in the basic design models of horizontal configurations in treatment wetlands with the aim to provide further insights on their influence to wetland performances. The VF system was not reviewed because they are recent breed of CW technology with much fewer performance data compared to the HF systems available. To achieve this, the evolution of $\mathrm{CW}$ design for pollutant removal in horizontal systems has been reviewed highlighting reasons for the development of newer models. The review focuses on the following:

- The generic Kickuth form equation and its suitability for sizing $\mathrm{CW}$ and predicting treatment efficiency,

- The operational and design parameter(s) primarily influencing $\mathrm{CW}$ performance.

\section{Models of Horizontal Subsurface Flow Systems}

The principle of the design for CWs subsurface flow (SSF) systems is based on an assumption of plug flow movement of water through the wetland with first-order reaction kinetics primarily by biological degradation. As an attached biological reactor involving microbes, modelling CWs typically combines biological degradation and system hydraulics. The basic relationship which has been used to simultaneously describe the two components mentioned above is given as:

$C_{e}=C_{i} \exp [-K \tau]$

Where $C_{e}\left(\mathrm{mg} \mathrm{L}^{-1}\right)$ is effluent concentration, $C_{i}\left(\mathrm{mg} \mathrm{L}^{-}\right.$ $\left.{ }^{1}\right)$ influent concentration, $K$ (days $\left.{ }^{-1}\right)$ is a temperaturedependent first order reaction rate constant and $\tau$ (days) is hydraulic residence time. The principle of the design for horizontal flow (HF) SSF systems is based on Equation 1 and is written as:

$A_{h}=Q_{d} \ln \left(C_{e}-C_{i}\right) / K_{B O D}$

Where $A_{h\left(\mathrm{~m}^{2}\right)}$ is the surface area of the bed, ${ }_{d}\left(\mathrm{~m}^{3} \mathrm{~d}^{-}\right.$ $\left.{ }^{1}\right)$ is average flow, $C_{i}\left(\mathrm{mg} \mathrm{L}^{-1}\right)$ is influent $\mathrm{BOD}_{5}, C_{e}(\mathrm{mg}$ $\left.\mathrm{L}^{-1}\right)$ is effluent $\mathrm{BOD}_{5}$ and $\mathrm{K}_{\mathrm{BOD}}\left(\mathrm{m} \mathrm{d}^{-1}\right)$ is the $\mathrm{BOD}$ rate constant. Equation (2) was originally proposed by Professor Kickuth in Germany ${ }^{15}$ with $\mathrm{K}_{\mathrm{BOD}}$ having a value of $0.19 \mathrm{~m}$ day ${ }^{-1[16]} \mathrm{K}$ is selected based on a 95 percentile BOD removal using Equation (2). Average $\mathrm{K}_{\mathrm{BOD}}$ of operational treatment wetlands reported in the literature is presented in Table 2 . The $\mathrm{K}_{\mathrm{BOD}}$ value varies and this has been reported to be due to the influence or biodegradability of the influent water and the type of media used in the bed ${ }^{17}$.

Table 2. Average $K_{\mathrm{BOD}}$ of treatment wetland reported for different countries

\begin{tabular}{llll}
\hline Country & Treatment & $\mathrm{K}\left(\mathrm{md}^{-1}\right)$ & reference \\
& application & & \\
\hline Denmark & Secondary & 0.068 & IWA, 2000 \\
Czech & Secondary & 0.13 & Vymazal et al, 1998 \\
UK & Secondary & 0.06 & Cooper et al., 1996 \\
UK & Tertiary & 0.31 & Cooper et al, 1996 \\
USA & Tertiary & 0.17 & IWA, 2000 \\
\hline
\end{tabular}

Design based on Equation 2 has generally been used to construct horizontal $\mathrm{CWs}$ and predict removal performance for organic matter usually expressed as BOD in constructed wetlands in Europe ${ }^{18-19}$, Australia $^{20}$ and the $\mathrm{US}^{21}$. To date, there has been no published design equation for the construction of horizontal flow systems based on the removal of other pollutants such as microbial indicators, suspended solids, nitrogen and phosphorous other than organics. The removal of these pollutants has been based on Equation $2^{22-23}$ assuming that adequate removal occurs if the design is suitable for BOD.

During the construction of SSF wetlands, bed slope and cross sectional area are selected to encourage plug flow through the bed and avoid flow over the bed surface. Bed slope in the lower range of $1-5 \%$ is commonly used whilst the hydraulic gradient for the whole bed is increased by progressively lowering the outlet ${ }^{24}$. Bed cross sectional area (also known as aspect ratio-i.e. length: width ratio) for the bed is usually calculated from Darcy's Law given as:

$$
A_{C}=\frac{Q_{s}}{K_{f} *(d H / d S)}
$$

Where $A_{C}\left(\mathrm{~m}^{2}\right)$ is the cross sectional area of the bed, $Q_{s}\left(\mathrm{~m}^{3} \mathrm{~s}^{-1}\right)$ is average flow, $K_{f}\left(\mathrm{~m} \mathrm{~s}^{-1}\right)$ is hydraulic conductivity and $d H / d S\left(\mathrm{~m} \mathrm{~m}^{-1}\right)$ is the slope of the bed.

Examples of hydraulic conductivity of media of operational treatment wetlands reported in the literature are $10^{-6} \mathrm{~m} \mathrm{~s}^{-1}$ for peat substrate treating landfill leachate ${ }^{25}$ and $1.91 \times 10^{-4} \mathrm{~m} \mathrm{~s}^{-1}$ with a pore volume of $30 \%$ for a sand media substrate treating grey water ${ }^{26}$. The slopes of operational $\mathrm{CW}$ systems usually range between $1-5 \%$. 
Examples of slope for HSSF beds from inlet to outlet are: $1 \%$ in a gravel bed treating household wastewater ${ }^{22}, 2 \%$ for a CW polishing municipal treated effluent ${ }^{27-28}$ used a $10 \mathrm{~cm}$ slope to enhance flow from inlet through the outlet of the bed whilst in a CW polishing sewage effluent, a bed slope of $0.1 \%$ was used in the design ${ }^{29}$.

\section{Evolution of horizontal flow SSF CW models}

\section{First order models}

An amendment to Equation 2 (Kickuth model) to reflect treatment wetland performance data was developed by Kadlec and Knight ${ }^{30}$. The model commonly referred to as the K-C* model differs from the original Kickuth equation in two ways: Firstly, it is a reversible first-order reaction equation rather than the irreversible equation and secondly it includes a non-zero background concentration. It is believed that an irreversible firstorder model does not satisfactorily describe removal of pollutants from treatment wetlands because pollutants in the treated water cannot be reduced to zero due to the subsequent release of pollutants from the wetland into the treated water ${ }^{30}$. Thus the non-zero background concentration represents release of pollutants resulting from transformation processes within the sediments and sediment water interactions. These processes are mainly attributed to production of organics from the decomposition of plant litter and other organic materials as well as endogenous autotrophic processes ${ }^{16,31}$. Background concentrations of BOD lie in the range of 1$10 \mathrm{mg} \mathrm{L}^{-1[16]}$. The $\mathrm{K}-\mathrm{C}^{*}$ model is written as:

$\ln \left(\frac{C_{e}-C^{*}}{C_{i}-C^{*}}\right)=\frac{K_{v} h \varepsilon A}{Q}=-\frac{K A}{Q}$

Where: $\mathcal{E}$ (dimensionless) is porosity, $h_{(\mathrm{m})}$ is water depth, $K_{v}\left(\right.$ days $\left.^{-1}\right)$ is volumetric rate constant and $\mathrm{C}^{*}\left(\mathrm{mg} \mathrm{L}^{-1}\right)$ is non-zero background $\mathrm{BOD}_{5}$.

Values of $\mathrm{K}$ and $\mathrm{C}^{*}$ vary from one wetland to another and depend on site-specific factors such as vegetation type and density, strength of influent wastewater, temperature and hydraulic variable ${ }^{17,30,32}$.

The K-C* model does not include a water balance across the wetland. Kadlec ${ }^{31}$ proposed an amended form of the K-C* model (Equation 5) which incorporates the effects of precipitation and evapotranspiration. Precipitation causes a dilution effect whilst evapotranspiration causes a concentration effect. Thus, both precipitation and evapotranspiration to some extent influences the system hydraulics ${ }^{17}$.

$$
\frac{C_{e}-C}{C_{i}-C^{\prime}}=\left(1+[\alpha y / q]^{-\left(1+K_{A} / \alpha\right)}\right.
$$

$C^{\prime}=C^{*}\left[\frac{K_{A}}{K_{A}+a}\right]$

Where, $\square$ is Precipitation $\left(\mathrm{m} \mathrm{d}^{-1}\right)$ evapotranspiration $\left(\mathrm{m} \mathrm{d}^{-1}\right), \mathrm{q}\left(\mathrm{m} \mathrm{yr}^{-1}\right)$ is hydraulic loading rate, $\mathrm{y}(\mathrm{m})$ is fractional distance through wetland (i.e. distance from inlet per length of wetland), $a$ is a constant equal to $\mathrm{K}$ for SSF wetland with Dacian flow and other terms carry their meaning as previously defined.

Further development of the model by Shepherd et al., ${ }^{33}$ presented a two parameter time-dependent retardation model for COD removal in a high waste stream. The model is based on the assumption that a high waste stream contains multiple pollutants of variable ease of degradation. As a result, easily degradable substances with faster removal kinetics are gradually replaced with less biodegradable substances with slower removal kinetics. The result is a time dependent constant described as:

$$
K_{v}=\frac{K_{o}}{(b \tau+1)}
$$

where $K_{v}\left(\right.$ days $\left.^{-1}\right)$ is time dependent rate constant,
$K_{o}\left(\right.$ days $\left.^{-1}\right)$ is the initial degradation rate constant,
$b_{\left(\text {days }^{-1}\right) \text { is a time-based retardation coefficient }\left(\text { days }^{-1}\right)}$
and $\tau$ (days) is the retention time.

Incorporating Equation 7 into a simple plug flow model gives a time dependent retardation model (equation 8):

$$
\frac{C}{C_{o}}=\exp \left[\left(\frac{-K_{o}}{b}\right) \ln (b \tau+1)\right]
$$

The model seeks to account for the steady decrease in pollutant concentration with increased treatment time rather than a constant residual (i.e. background) value.

The limitation of first order models for the design of treatment wetlands has been recognised ${ }^{17}$ because oneparameter, two-parameter and three-parameter versions all attain saturation (i.e. $\mathrm{C} \neq 0$ ) with increasing retention time. This effect worsens with a one-parameter model having a greater variability in background concentration $\left(\mathrm{C}^{*}\right)$. Three parameter models do correct for dispersion of the non-ideal behaviour but cannot correct the degree of treatment influenced by short-circuiting ${ }^{17}$. Evidently, none of the one, two or three parameter models are independent of operating conditions thus highlighting the importance of wetland hydraulics in improving design models. 


\section{Monod-type model}

The findings of Mitchell and McNevin ${ }^{34}$ further throw light on the limitations of existing first-order parameter models. They explained the limitation to first order models as due to the fact that biological systems will normally operate under Monod-type kinetics where degradation rates are limited by pollutant availability at relatively low concentration but would reach saturation at relatively high concentrations. Their model identified that most wetlands are operating well below their expected maximum performance partly because they are undersized and estimated that maximum loading for SSF wetlands approximates to $80 \mathrm{~kg} \mathrm{ha}^{-1} \mathrm{~d}^{-1}$ for BOD based on USEPA wetland data in North America. The Mitchell and McNevin proposed Monod model is given as:

$$
r=K_{o, v} V \frac{C}{K+C}
$$

where $r$ is the rate of biological degradation and $K$ is the half saturation constant and $\mathrm{C}\left(\mathrm{mg} \mathrm{L}^{-1}\right)$ is pollutant concentration. The contaminant concentration is normalised against the half saturation constant against the total length of the wetland bed $Z$ given as:

$$
\frac{d C}{d Z}=-\Omega \frac{C}{1+C}
$$

and a normalised removal rate $\left(R_{R}\right)$ given as:

$R_{R}=\frac{C_{\text {in }}-C_{\text {out }}}{\Omega}$

where $\mathrm{Z}(\mathrm{m})$ is the length of the wetland bed, $\Omega$ indicates the relative effectiveness of the wetland bed and normalizes the maximum possible mass removal on a volumetric basis for a given hydraulic residence time or flow rate. A high value of $\Omega$ means that the degradation rate is high compared with the flow rate which leads to better performance.

Although the limitations in the original Kickuth equation for designing and predicting pollutant removal performance have been recognised ${ }^{30}$ and various attempts made to address them through the development of models believed to correspond better with wetlands performance $e^{30,32,34}$, it is the equation still widely used to design treatment wetland processes ${ }^{16,30,34}$. This is because some of these recent models would require very large amount of data for proper calibration ${ }^{16}$. In addition it is still uncertain whether detailed models will provide more accurate descriptions of wetland performance in light of the variability displayed by wetland data $^{30}$. As the processes involved in CWs is complex and difficult to predict, this technology at present is limited to organic loading guidelines ${ }^{16}$.

\section{Critical review of horizontal flow systems}

To investigate the influence of design and operating conditions on wetlands performance, influent and effluent pollutant concentrations (mg. $\mathrm{L}^{-1}$ ) and design parameters (flow rates, hydraulic loading and residence times) from 38 published studies were used to create a database. Literature was selected to cover the operational range of $0.01-0.10 \mathrm{~m} \mathrm{~d}^{-1}$ hydraulic loading as most treatment wetlands reported in the literature lie within this range $e^{35,36}$. Operational parameters were adopted as given in literature. When hydraulic loading or residence time was not given, they were calculated from Equations 12 and 13. Details of operational and water quality parameters used in this case study are given in Appendix 7.

$$
\begin{aligned}
& H L R=\frac{Q}{A} \\
& H L R=\frac{\varepsilon h}{\tau}
\end{aligned}
$$

Where HLR $\left(\mathrm{m} \mathrm{d}^{-1}\right)$ is hydraulic loading rate, $Q\left(\mathrm{~m}^{3} \mathrm{~d}^{-1}\right)$ is flow rate, $\mathrm{A}\left(\mathrm{m}^{2}\right)$ is area of bed, $\varepsilon$ is porosity of bed media, $\mathrm{h}(\mathrm{m})$ is bed depth and $\tau(\mathrm{d})$ is residence time. Value of $\varepsilon$ (porosity or the fraction of space through which water can flow in the wetland) adopted was 0.75 for SF and 0.4 for $\mathrm{SSF}^{16}$. Pollutant removal efficiency was calculated as percent mass removal given as:

$$
100 \frac{m_{i}-m_{o}}{m_{i}}
$$

Where $m_{i}$ and $m_{0}$ are mass loading of inflow and outflow respectively.

The variables analyzed were influent and effluent loading of the following water quality parameters (BOD, COD, $\mathrm{TSS}, \mathrm{NH}_{4}-\mathrm{N}, \mathrm{NO}_{3}-\mathrm{N}, \mathrm{PO}_{4}-\mathrm{P}$ and total coliforms), removal efficiencies according to Equation (11) and HLR. Variables were analyzed by graphical plots with the aid of Microsoft regression equations, Spearman correlation ranking and $\mathrm{F}$ statistics.

\section{Wetlands performance}

\section{Removal efficiency of pollutants in treatment wetlands}

Results show that the ability of treatment wetlands to remove BOD, COD, TSS and coliforms from influent wastewater is greater (i.e. $73-83 \%$ ) than for nutrients $(30-45 \%)$. This result is consistent with the literature. For instance, Vymazal37 reported that total nitrogen and phosphorous removal in most $\mathrm{CW}$ is low compared to organics and solids and varied between $40-55 \%$ for nitrogen removal and $40-60 \%$ for phosphorous removal respectively. This is because the processes that affect nitrogen removal in $\mathrm{CWs}$ include nitrification and 
denitrification, and most treatment wetlands (e.g. horizontal or vertical system) cannot achieve high removal of total nitrogen or ammonia and nitrate nitrogen because of their inability to provide oxic conditions for nitrification and anoxic condition for denitrification simultaneously. To illustrate, horizontal systems being saturated and anoxic-anaerobic provide suitable conditions to achieve denitrification (Equation 1) whilst vertical flow systems being unsaturated and oxic successfully provide the conditions for nitrification (Equation 2). Thus, horizontal flow systems are limited in nitrification whilst vertical flow systems are limited in denitrification. Denitrification occurs in the presence of available organic substances and can be illustrated by the following equation:

$$
6\left(\mathrm{CH}_{2} \mathrm{O}\right)+4 \mathrm{NO}_{3}^{-} \rightarrow 6 \mathrm{CO}_{2}+2 \mathrm{~N}_{2}+6 \mathrm{H}_{2} \mathrm{O}
$$

Nitrification is executed by chemolithotrophic (aerobic) bacteria which are dependent on the oxidation of ammonia for the generation of energy for growth. The overall nitrification process can be represented as:

$$
\mathrm{NH}_{4}^{+}+2 \mathrm{O}_{2} \rightarrow \mathrm{NO}_{3}^{-}+2 \mathrm{H}^{+}+\mathrm{H}_{2} \mathrm{O}
$$

Removal of phosphorous in several treatment wetlands has been low because the substrates traditionally employed for municipal/domestic wastewater in treatment wetlands (e.g. sands and gravels) do not have high enough sorption capacity.

Furthermore, most treatment wetlands are effective in removing organics from influent wastewater because they are primarily designed to remove organic matter and solids1. Removals up to $95 \%$ can easily be achieved if the systems are not overloaded. The high and comparable removal efficiencies amongst BOD, COD, TSS and coliforms is because significant amount of solids in wastewater is organic in nature, and consequently, reduction of solids corresponds with organic reduction 22,38 .

Evaluation of wetlands overall performance using 1:1 plot in removing pollutants from wastewater revealed that removal efficiency was lower than the expected based on the 95 percentile calculated from the Kickuth equation. Corresponding plots of predicted effluent concentrations based on the 95 percentile versus measured effluent concentrations for all water quality parameters showed data points well below the 1:1 removal line (Figures 1a to 8a). The 1:1 removal line represents the $100 \%$ efficiency line. Although $100 \%$ would not be achieved in a real situation because of subsequent release of organics from the wetland into the effluent waste stream 30 , the further the points lie to the right of the 95 percentile removal line indicates the more undersized the wetlands are for the particular application resulting in sub-optimal wetland performance34. Although correlation coefficients for all parameters were low indicating that the removal of pollutants were poorly predicted by the first order or Kickuth model, evaluation from the line fitting plots also revealed that measured versus predicted concentrations for BOD, COD, TSS and total coliforms correlated better ( $\mathrm{r} 2$ values in the range of $0.24-0.32$ ) compared to $\mathrm{r} 2$ values of $0.08-0.16$ for nutrients (Figure 1a-8a). This indicate that the removal of BOD, COD, TSS and total coliforms from wastewater by treatment wetlands were better described and predicted by the models used to design these wetlands. Indeed, it is known that all design equations for pollutant removal and treatment performance in treatment wetlands are based on BOD despite recognising that removal of nutrients from wetlands cannot be adequately described the same way as organics due to different pollutant removal pathways 39 .

Rousseau et al.,40 in a study of model design of horizontal subsurface wetlands obtained different surface area from different models for treatment wetlands using a single influent and effluent data set. He found that a simple "rule of thumb" model predicts several orders of magnitude of surface area larger than first order (including Kikuth model), regression and retardation models. He further reported large differences between minimum and maximum calculated surface area by each of these models due to parameter uncertainty (i.e. rate constants and background concentrations). Rate constants and background concentrations have been reported to be strongly dependent on hydraulic loading and influent concentration, which consequently renders first order models incapable of acceptable performance design 17 . Calculation for area based rate constants from collated data in this study ranged from 0.02 to 0.34 m.d-1 for domestic/municipal waste water. Despite the extreme of this area based rate constant calculated, the mid range values are comparable to that of the mid-range area-base rate constants in the range of 0.06 to 1.00 reported by Rousseau et al.,40.

According to first order design models which most wetland designs are based on; $\mathrm{K}$ values from treatment wetlands should ideally be within a narrow range. However, such large variations obtained from operational treatment wetlands reflect the impact of wetland age, influent concentration and hydraulic loading ${ }^{43,17,32}$. These collective factors are difficult to account for accurately in any model as wetland age varies for any particular wetland and organic matter release from wetlands are influenced by local conditions. Addressing these factors would produce a complex model which would be difficult to calibrate and apply. 
Table 3. Regression summary for the effect of operational parameters on effluent BOD.

\begin{tabular}{|l|l|l|}
\hline Parameter & \multicolumn{1}{|c|}{ Surface flow } & \multicolumn{1}{c|}{ Subsurface flow } \\
\hline Inf vs Eff loading & $\mathrm{y}=1.02 \mathrm{x}-1.12, \mathrm{R}^{2}=0.99, \mathrm{n}=35$ & $\mathrm{y}=0.26 \mathrm{x}-0.01, \mathrm{R}^{2}=0.86, \mathrm{n}=81$ \\
\hline $\begin{array}{l}\text { Inf loading vs \% } \\
\text { removal }\end{array}$ & $\mathrm{y}=-0.46 \mathrm{x}+53.1, \mathrm{R}^{2}=0.07, \mathrm{n}=35$ & $\mathrm{y}=-0.09 \mathrm{x}+53.1, \mathrm{R}^{2}=0.01, \mathrm{n}=81$ \\
\hline HLR vs \% removal & $\mathrm{y}=11.5 \mathrm{x}+2.34, \mathrm{R}^{2}=0.10, \mathrm{n}=35$ & $\mathrm{y}=64.4 \mathrm{x}+0.43, \mathrm{R}^{2}=0.95, \mathrm{n}=81$ \\
\hline
\end{tabular}

Table 4. Regression summary for the effect of operational parameters on effluent COD.

\begin{tabular}{|l|l|l|}
\hline Parameter & \multicolumn{1}{|c|}{ Surface flow } & \multicolumn{1}{c|}{ Subsurface flow } \\
\hline Inf vs Eff loading & $\mathrm{y}=0.24 \mathrm{x}+5.82, \mathrm{R}^{2}=0.81, \mathrm{n}=23$ & $\mathrm{y}=0.44 \mathrm{x}-2.07, \mathrm{R}^{2}=0.91, \mathrm{n}=42$ \\
\hline $\begin{array}{l}\text { Inf loading vs \% } \\
\text { removal }\end{array}$ & $\mathrm{y}=0.03 \mathrm{x}+51.6, \mathrm{R}^{2}=0.08, \mathrm{n}=23$ & $\mathrm{y}=-0.10 \mathrm{x}+70.2, \mathrm{R}^{2}=0.07, \mathrm{n}=42$ \\
\hline HLR vs \% removal & $\mathrm{y}=-7.07 \mathrm{x}+60.6, \mathrm{R}^{2}=0.02 \mathrm{n}=23$ & $\mathrm{y}=-131.4 \mathrm{x}+74.2, \mathrm{R}^{2}=0.15, \mathrm{n}=42$ \\
\hline
\end{tabular}

Table 5. Regression summary for the effect of operational parameters on effluent SS.

\begin{tabular}{|l|l|l|}
\hline Parameter & \multicolumn{1}{|c|}{ Surface flow } & \multicolumn{1}{c|}{ Subsurface flow } \\
\hline Inf vs Eff loading & $\mathrm{y}=0.69 \mathrm{x}-1.10, \mathrm{R}^{2}=0.98, \mathrm{n}=19$ & $\mathrm{y}=0.50 \mathrm{x}-10.7, \mathrm{R}^{2}=0.99, \mathrm{n}=49$ \\
\hline $\begin{array}{l}\text { Inf loading vs \% } \\
\text { removal }\end{array}$ & $\mathrm{y}=-0.04 \mathrm{x}+40.8, \mathrm{R}^{2}=0, \mathrm{n}=19$ & $\mathrm{y}=0.04 \mathrm{x}-64.0, \mathrm{R}^{2}=0.17, \mathrm{n}=49$ \\
\hline HLR vs \% removal & $\mathrm{y}=-5.82 \mathrm{x}+41.2, \mathrm{R}^{2}=0.01, \mathrm{n}=19$ & $\mathrm{y}=-0.41 \mathrm{x}+73.5, \mathrm{R}^{2}=0.02, \mathrm{n}=49$ \\
\hline
\end{tabular}

Table 6. Regression summary for the effect of operational parameters on effluent $\mathrm{NH}_{4}-\mathrm{N}$.

\begin{tabular}{|l|l|l|}
\hline Parameter & \multicolumn{1}{|c|}{ Surface flow } & \multicolumn{1}{c|}{ Subsurface flow } \\
\hline Inf vs Eff loading & $\mathrm{y}=0.60 \mathrm{x}+0.07, \mathrm{R}^{2}=0.95, \mathrm{n}=23$ & $\mathrm{y}=0.50 \mathrm{x}+1.09, \mathrm{R}^{2}=0.79, \mathrm{n}=51$ \\
\hline $\begin{array}{l}\text { Inf loading vs \% } \\
\text { removal }\end{array}$ & $\mathrm{y}=0.04 \mathrm{x}+37.1, \mathrm{R}^{2}=0.5, \mathrm{n}=23$ & $\mathrm{y}=0.03 \mathrm{x}-36.5, \mathrm{R}^{2}=0, \mathrm{n}=51$ \\
\hline HLR vs \% removal & $\mathrm{y}=0.60 \mathrm{x}+0.07, \mathrm{R}^{2}=0.95, \mathrm{n}=23$ & $\mathrm{y}=0.51 \mathrm{x}+1.1, \mathrm{R}^{2}=0.79, \mathrm{n}=51$ \\
\hline
\end{tabular}

Table 7. Regression summary for the effect of operational parameters on effluent $\mathrm{NO}_{3}-\mathrm{N}$.

\begin{tabular}{|l|l|l|}
\hline Parameter & \multicolumn{1}{|c|}{ Surface flow } & \multicolumn{1}{c|}{ Subsurface flow } \\
\hline Inf vs Eff loading & $\mathrm{y}=0.30 \mathrm{x}+0.21, \mathrm{R}^{2}=0.69, \mathrm{n}=19$ & $\mathrm{y}=0.80 \mathrm{x}+0.07, \mathrm{R}^{2}=0.37, \mathrm{n}=14$ \\
\hline $\begin{array}{l}\text { Inf loading vs \% } \\
\text { removal }\end{array}$ & $\mathrm{y}=7.70 \mathrm{x}-5.02, \mathrm{R}^{2}=0.07, \mathrm{n}=19$ & $\mathrm{y}=1349 \mathrm{x}-752.9, \mathrm{R}^{2}=0.06, \mathrm{n}=14$ \\
\hline HLR vs \% removal & $\mathrm{y}=-33.3 \mathrm{x}+26.3, \mathrm{R}^{2}=0.05, \mathrm{n}=19$ & $\mathrm{y}=3527.6 \mathrm{x}-781.7, \mathrm{R}^{2}=0.04, \mathrm{n}=14$ \\
\hline
\end{tabular}

Table 8. Regression summary for the effect of operational parameters on effluent $\mathrm{PO}_{4}-\mathrm{P}$.

\begin{tabular}{|l|l|l|}
\hline Parameter & \multicolumn{1}{|c|}{ Surface flow } & \multicolumn{1}{c|}{ Subsurface flow } \\
\hline Inf vs Eff loading & Not investigated & $\mathrm{y}=0.65 \mathrm{x}-0.04, \mathrm{R}^{2}=0.92, \mathrm{n}=38$ \\
\hline $\begin{array}{l}\text { Inf loading vs \% } \\
\text { removal }\end{array}$ & Not investigated & $\mathrm{y}=-3.93 \mathrm{x}+47.7, \mathrm{R}^{2}=0.01, \mathrm{n}=38$ \\
\hline HLR vs \% removal & Not investigated & $\mathrm{y}=29.1 \mathrm{x}+44.5, \mathrm{R}^{2}=0, \mathrm{n}=38$ \\
\hline
\end{tabular}




\section{Influence of operational parameters (hydraulic and influent loading) on pollutant removal}

\section{Organics}

Effluent organic loading (BOD 5 and COD) for both $\mathrm{SF}$ and SSF treatment wetlands showed strong positive correlation with influent organic loading (Tables $3 \& 4$, Figure $1 \mathrm{~b}$ and $3 \mathrm{~b}$ ). This indicates that the residual concentration of BOD in the effluent of most treatment wetlands was influenced by the inlet concentration. Vymazal $^{1}$ reported similar findings for 44 horizontal systems in the Czech Republic.

Influent organic loading has been proved to influence wetland performance as reflected in effluent residual $\operatorname{organics}^{16}$. The explanation is that up to an optimum loading, removal efficiencies increase as loading increases and correlate positively with mass loading rates. To illiustrate, Ghermandi et al., ${ }^{41}$ reviewed 25 tertiary surface flow treatment wetlands and found that in 19 cases, effluent BOD were below $10 \mathrm{mg} \mathrm{L}^{-1}$ when the systems were not overloaded in terms of influent organic loading, whereas in 3 cases, effluent exceeded $30 \mathrm{mg} \mathrm{L}^{-1}$ of which 2 were caused by higher than recommended influent BOD loading. Results from other operational wetlands for different types of waste water have also exhibited a similar effect of influent loading on effluent residual BOD concentrations ${ }^{42,43}$.

The effect of hydraulic loading on effluent organic loading though significant was much weaker $(\mathrm{p}<0.05$, Figure $1 \mathrm{c} \& 3 \mathrm{c})$. Evaluation of the plots of HLR versus BOD (Figures $1 \mathrm{c}$ and $2 \mathrm{a} \& \mathrm{~b}$ ) indicates that removal efficiency of organics decreased with increased HLR. This is consistent with the literature ${ }^{39,42,44-46}$, where it has been reported that organic removal efficiency is improved at lower HLR. Figure 2 ( $a$ and b), showed the effect of gravel and sand/soil substrate on the removal of BOD organics over a range of HLR and influent loading in SSF wetlands. In both substrate types (except gravel for influent loading versus removal), removal efficiency decreases with increased HLR. However, the relationship for gravel substrate is much looser/weaker compared to sand and soil suggesting that the effect of HLR and influent loading on the removal of organic matter is much more pronounced in treatment wetlands having sand or soil substrate.

A possible explanation for this is that increased HLR results in increased organic and suspended solids loading. Depending on the nature and loading of solids, increased TSS loading may result in bed surface clogging and soil/sand media are much more susceptible to clogging and surface overflow compared to gravel. Clogging and overflow of a bed usually result in poor effluent quality.

\section{Suspended Solids (SS)}

Strong correlations were observed between influent and effluent SS loading for both SF and SSF designs (Figure 4b). The overall efficiency of SS removal in terms of surface loading averaged $60 \%$ for subsurface flow and $34 \%$ for surface flow. The difference in percentage between SF and SSF reflects the removal mechanisms of solids in both wetland types. There is greater contact between the water and the wetland media as water flows through an SSF which encourages filtration compared to SF. Removal of SS correlated weakly with influent load $\left(\mathrm{R}^{2}=0.17\right)$ for SSF whilst no relationship was evident between the two for SF. The HLR virtually did not show any effect on SS removal for both systems (Table 5).

The plot of HLR against SS removal shows that for both SF and SSF systems, removal efficiency decreases as HLR increases and that maximum efficiency tends to be

achieved within a narrow range of SS (Figure 4c). These findings are in line with Reddy et al., ${ }^{47}$ who found no relationship between SS removal and SS mass loading in a SF CW whereas Gearheart ${ }^{48}$ reported approximately $75 \%$ of TSS removal in the first day retention in his study. Solids removal in treatment wetlands is primarily due to physical processes such as filtration and sedimentation as wastewater passes through the media, much of which can be retained around the inlet bed ${ }^{47,19}$. As a result, wetland outlet SS data reflects background concentrations (i.e. C*) and not necessarily wetland dynamics or operational characteristics. SS removal in SSF CW is therefore not strongly sensitive to HLRs ${ }^{16}$. The observed removal pattern of solids in wetlands would also mean that an increase in removal rate will not be observed as loading increases as indicative of first order kinetics, but rather will increase at low concentration and tend towards zero order at high concentration as hypothesized by Mitchell and $\mathrm{McNevin}^{33}$

\section{Nutrients $\left(\mathrm{NH}_{4}-\mathrm{N}, \mathrm{NO}_{3}-\mathrm{N}, \mathrm{PO}_{4}-\mathrm{P}\right)$}

Influent loading correlated strongly with effluent loading for both $\mathrm{NH}_{4}-\mathrm{N}$ and $\mathrm{NO}_{3}-\mathrm{N}$. However, influent loading did not correlate with $\mathrm{NH}_{4}-\mathrm{N}$ or $\mathrm{NO}_{3}-\mathrm{N}$ mass removal (Tables $6 \& 7$, Figures $5 \& 6$ b \& d).

$\mathrm{N}$ removal in wetlands undergo complex sequential transformation processes each requiring specific environmental conditions. Operational design for significant nitrogen removal therefore has to ensure oxic conditions for nitrification and anoxic conditions for denitrification. Mass removal of $\mathrm{NH}_{4}-\mathrm{N}$ and $\mathrm{NO}_{3}-\mathrm{N}$ did not correlate with HLR (Tables $6 \& 7$; Figure $5 \& 6 c$ ) indicating that removal of these nutrients is not influenced by HLR. These observations further indicate the importance of other factors influencing $\mathrm{NH}_{4}-\mathrm{N}$ or $\mathrm{NO}_{3}-\mathrm{N}$ removal but which are not included in simple regression relationships. Hence reported $\mathrm{N}$ removal from treatment wetlands is generally lower than BOD, COD and $\mathrm{TSS}^{39}$ and highly variable.

For phosphate, only the relationship between influent and effluent P loading was significant (Tables 8, Figure 7b).

$\mathrm{P}$ removal in treatment wetlands is also complex and variable. Removal is dependent mainly on the nature of the bed media which is the major sink for $\mathrm{P}$ in wetlands. 
Generally, P removal involves both biotic (uptake by vegetation, periphyton and microbes; mineralization of plant litter and soil organic phosphorous) and abiotic (sedimentation and burial; adsorption and precipitation; exchanges between soil and overlying water column) processes $^{47}$. Chick and Mitchell ${ }^{49}$ found that these processes are favoured by longer retention times whilst Sun et al. ${ }^{50}$ reported $\mathrm{P}$ removal not to be affected by increased contact time since inorganic chemical reactions are normally rapid. The soil/litter compartment is the major long-term storage pool for phosphorous, though some may eventually be released to the water column under less reducing conditions and when sorption sites became saturated/unavailable ${ }^{51,52}$. Although regression analysis indicates no relationship between inflow $\mathrm{P}$ loading and removal efficiency, generally, the plot shows a decrease in removal efficiency with increased loading. Geary and Moore ${ }^{51}$ reported sensitivity of $\mathrm{P}$ removal to HLR possibly because of the ability of the substrate to sorb phosphorous.

\section{Coliforms}

With the exception of influent and effluent loading of coliform counts where strong correlations was evident (Table 9, Figure $8 \mathrm{~b}$ ), coliform removal was very weakly correlated to HLR and influent loading for both SF and SSF wetlands (Table 9, Figures 8c \& d).

\section{Conclusion}

Results from this case studied showed that despite high removal efficiency reported for most wetlands, residual concentrations e.g. for BOD are frequently higher than those predicted based on the 95 percentile first-order Kickuth design equation. This observation was attributed to most wetlands being undersized and high hydraulic loading applications implying that sizing and predicting CWs performance cannot be primarily predicted based on Equation 2 alone. Also correlation results indicate that hydraulic and pollutant loading strongly influence wetland performance for organic removal (BOD, COD). In all cases, removal generally decreases as loading increases. Hydraulic loading was not found to correlate with nutrient removal. This highlights the need to incorporate other operational parameters for the efficient removal of nutrients in wetlands. Overall, it can be concluded that organic removal will be earsier to model in treatment wetlands (e.g. horizontal systems) compared to nutrients because their removal can be influenced primarily by the design parameters (HLR and influent loading) whilst other factors (e.g. aerobic conditions, redox potential, environmental conditions) in addition to HLR and influent loading influence removal of nutrients in treatment wetlands. Because the removal of solids and indicator organisms (coliforms) are not primarily influenced by the key design parameters (HLR and influent loading), it is expected that they will fit into any design model developed.

Table 9. Regression summary for the effect of operational parameters on effluent total coliforms.

\begin{tabular}{llll}
\hline Parameter & \multicolumn{1}{c}{ Surface flow } & Subsurface flow \\
\hline Inf vs Eff loading & & $\mathrm{y}=0.16 \mathrm{x}-2489, \mathrm{R}^{2}=0.70, \mathrm{n}=35$ & $\mathrm{y}=0.70 \mathrm{x}-74168, \mathrm{R}^{2}=0.95, \mathrm{n}=35$ \\
Inf loading vs & $\%$ & $\mathrm{y}=6.21 \mathrm{x}-126.6, \mathrm{R}^{2}=0.20, \mathrm{n}=35$ & $\mathrm{y}=8.87 \mathrm{x}+35.63, \mathrm{R}^{2}=0.39, \mathrm{n}=35$ \\
removal & & & \\
HLR vs \% removal & $\mathrm{y}=14.1 \mathrm{x}+46.4, \mathrm{R}^{2}=0.17, \mathrm{n}=35$ & $\mathrm{y}=-0.62 \mathrm{x}+65.7, \mathrm{R}^{2}=0.04, \mathrm{n}=35$ \\
\hline
\end{tabular}

High removal of indicator organisms is generally reported for treatment wetlands despite varying influent load and hydraulic loading. For instance, Soto et al., ${ }^{53}$ with an influent count of 7-8 order higher than that in Vymazal et al., ${ }^{36}$ reported removal efficiency of $99.9 \%$ and $99.3 \%$ respectively. Also, da Motta Marques et al., ${ }^{44}$ reported removal efficiency of $99 \%$ coliform removal at HLR of $6.7 \mathrm{~cm} . \mathrm{d}^{-1}$ compared to $88 \%$ at HLR of 13.7 $\mathrm{cm} \cdot \mathrm{d}^{-1}$. High removal rates characterised by rapid decline to background concentrations for coliforms in treatment wetlands $^{16}$ is indicative of the fact that removal of coliforms from treatment wetlands is not primarily influenced by HLR or influent load. An explanation for this could be due to the combined physical, chemical and biological factors responsible for the removal of microbial indicators from CWs. Physical factors include filtration, sedimentation, and aggregation and ultra-violet ray action. Chemical factors include oxidation, adsorption and exposure to toxins given off by other microorganisms and plants. Biological mechanisms include antibiotics, ingestion by nematodes or protozoans, lytic bacteria and bacteriophages attacks and natural die-off'.

\section{References}

1. Vymazal, J. (2002). The use of sub-surface constructed wetlands for wastewater treatment in the Czech Republic: 10 years experience. Ecological Engineering, 18 (5), 633-946.

2. Dotro, G., Fitch, M., Larsen, D and Palazolo, P. (2006). Treament of Chromium-bearing wastewaters from tannery opertions with constructed wetlands. Proceedings of 10th International Conference on Wetlands System for Water Pollution Control. Lisbon, Portugal, Vol III, 1725-1734, ISBN 989-20-0361-6.

3. Omari, K., Revitt, M., Shutes, B. and Garelick, H. (2003). Hydrocarbon removal in an experimental gravel bed constructed wetland. Wat. Sci. Tech., 48(5), 275-281.

4. Mays, P. A. and Edwards, G. S. (2001). Comparison of heavy metals accumulation in a natural wetland and constructed wetlands receiving acid mine drainage. Ecol. Eng. 16, 487-500. 
5. Tanner, C. C., Clayton, J. S. and Upsdell, M. P. (1995). Effect of loading rate and planting on treatment of dairy farm wastewaters in constructed wetlands-I. Removal of nitrogen and phosphorus. Wat. Res 29, 1, 27-34.

6. Carleton, J. N., Grizzard, T. J., Godrej, A. N., Post, H. E., Lampe, L, Kenel, Pomela, P. (2000). Performance of a constructed wetlands in treating urban stormwater runoff. Wat. Env. Res. 72 (3), 295-304.

7. Browne, W. and Jessen, P. D. (2005). Exceeding tertiary standards with a pond/reed bed system in Norway. Wat. Sci \& Tech., 51 (9), 299-306.

8. House, C. H., Bergmann, B. A., Stomp, A. M. and Frederick, D. J. (1999). Combining constructed wetlands and aquatic and soil filters for reclamation and reuse of water. Ecol. Eng. 12 (1-2), 27-38.

9. Ellis, J. B., Shutes, R. B. E. and Revitt, D. M. (2003). Constructed wetlands and links with Sustainable Drainage systems. R \& D Technical report P2-159/TR1, Environment Agency for England and Wales.

10. Kadlec, R. H. (2003). Effects of pollutant speciation in treatment wetland design. Ecol. Eng., 20 (1), 1-16.

11. Watson, J. T., Reed, S. C., Kadlec, R.H., Knight, R.L. and Whitehouse, A.E. (1989). Performance expectations and loading rates for constructed wetlands: In Constructed wetlands fort wastewater treatment: municipal, industrial and agricultural. Lewis publishers, Michigan. $319-351$.

12. Haberl, R., Perfler, R. and Mayer, H. (1995). Constructed wetlands in Europe, Wat. Sci \& Tech., 32 (3), 305-315.

13. Green, M. B., Martin, J. R. and Griffin, P. (1999). Treatment of combined sewer overflows at small wastewater treatment works by constructed reed beds, Wat. Sci \& Tech., 40 (3), 357-364.

14. Vymazal, J. (1999). Removal of BOD5 in Constructed wetlands with horizontal subsurface flow: Czech experience, Wat. Sci. Tech., 40(3), 133-138.

15. Boon, A. G. (1985). Report on visit by membranes and staff of WRc to Germany to investigate Root Zone Method for treatment of wastewaters, WRc Report 376-S/1, Stevenage, UK.

16. IWA (2000). Constructed Wetlands for Pollution Control: Processes, Performance, Design and Operation. Scientific and technical Report No.8, IWA Publishing, London, UK.

17. Kadlec, R. H. (2000). The inadequacy of firstorder treatment wetland models. Ecol. Eng. 15, (1-2), 105-119.

18. Vymazal, J., Brix, H., Cooper, P. F., Haberl, R., Perfler, R. and Laber, J. (1998). Removal mechanism and types of constructed wetlands.
In Constructed Wetlands for wastewater Treatment in Europe, eds j. Vymazal, H. Brix, P.F. Cooper, M.B. Green, (17-66). Backhuys Publishers, Leiden.

19. Cooper, P. A., Job, G. D., Green, M. B. and Shutes, R. B. E. (eds) (1996). Reed beds and constructed wetlands for wastewater treatment, WRc Publications, Swindon, UK. 184.

20. Mitchell, C. Wiese, R. and Young, R. (1998). Design of wastewater wetlands. In The Constructed Wetlands Manual, eds R. Young, G. White, M. Brown, J. Burton and B. Atkins, Vol. 2, 256-289. Department of Land \& Water Conservation, NSW, Sydney.

21. Reed, S. C., Crites, R. W., and Middlebroods, E. J. (1995). Natural systems for waste management and treatment. 2nd edition, McGraw-Hill, Inc, 433.

22. Neralla, S., Weaver, R. W., Lesikar, B.J.and Persyn, R.A. (2000). Improvement of domestic wastewater quality by subsurface flow constructed wetlands. Bioresource Technology 75, 19-25.

23. Cooper, P. (1999). A review of the design and performance of vertical-flow and hybrid reed bed treatment systems. Wat. Sci. Tech., 40(3), $1-9$.

24. Green, M. B. and Upton, J. (1994). Constructed reed beds: A cost effective way to polish wastewater effluents for small communities, Wat. Env. Res, 66 (3), 188-192.

25. Kinsley, C. B., Crolla, A. M., Kuyucak, N., Zimmer, M. and Lafleche, A. (2007). Nitrogen dynamics in a constructed wetland system treating landfill leachate. Wat. Sci. \& Tech 56(3), 151-158.

26. Shrestha, R. R., Haberl, R. and Laber, J. (2001). Constructed wetland technology transfer to Nepal. Wat. Sci. \& Tech 43(11), 345-350.

27. Cameron, K, Madramootoo, C. Crolla, A. and Kinsley, C. (2003). Pollutant removal from municipal sewage lagoon effluents with a freesurface wetland. Wat. Res. 37, 2803-2812.

28. Steer, D., Fraser, L., Boddy, J and Seibert, B. (2002). Efficiency of small constructed wetlands for subsurface treatment of singlefamily domestic effluent. Ecol. Eng. 18, 429440.

29. Combes, C. and Collett, P. J. (1995). Use of Constructed wetland to protect bathing water quality. Wat. Sci. \& Tech., 32(3), 149-158.

30. Kadlec, R. H. and Knight, R. L. (1996). Treatment wetlands, CRC Lewis, Boca Roton, FL, 893.

31. Bavor, H. J., Roser, D. J., Mckersie, S. A. and Breen, P. (1988). Joint study on sewage treatment lagoon-aquatic plant systems. Hawkesbury Agricultural College/CSIRO/Sydney Water Board, Sydney.

32. Stein, O. R., Towler, B. W., Hook, P. B. and Biederman, J. A. (2007). On fitting the K-C* 
first order model to batch loaded sub-surface treatment wetlands. Wat. Sci. \& Tech 56(3), 9399.

33. Shepherd, H., Tchobanoglous, G and Grismer, M.E. (2001). Time-dependent retardation model for chemical oxygen demand removal in a subsurface-flow constructed wetland for winery wastewater treatment. Wat. Env. Res 73(5). 597-606.

34. Mitchell, C. and McNevin, D. (2001). Alternative analysis of BOD removal in subsurface flow constructed wetlands employing Monod kinetics. Wat. Sci. Tech., 35(5), 1295-1303.

35. Tanner, C. C. (2001). Plant as ecosystem engineers in subsurface-flow treatment wetlands. Wat. Sci. Tech., 44(11-12), 9-18.

36. Vymazal, J. (2001). Types of constructed wetlands for wastewater treatment: their potential for nutrient removal. In: J. Vymazal, Editor, Transformations of Nutrients in Natural and Constructed Wetlands, Backhuys Publishers, Leiden, The Netherlands, 1-93.

37. Vymazal, J (2007). Removal of nutrients in various types of constructed wetlands. Science of the Total Environment 380, 48-65.

38. Gopal, B.(1999). Natural and constructed wetlands for wastewater treatment: Potentials and Problems. Wat. Sci. Tech., 40 (3), 27 - 35.

39. Kern, J. and Idler, C. (1999). Treatment of domestic and agricultural wastewater by reed bed systems. Ecol. Eng 12, 13-25.

40. Rousseau, D. P. L., Vanrolleghem, P. A. and de Pauw, N. (2004). Model-based design of horizontal subsurface flow constructed treatment wetlands: a review. Wat Res., 38 (6), $1484-1493$

41. Ghermandi, A., Bixio, D. and thoeye, C. (2007). The role of free water surface constructed wetlands as polishing step in municipal wastewater and reuse. Sci Total Env. 380, 247-258.

42. Langergraber, G. Prandtstetten, C. Pressl, A. Rohrhofer, R. and haberl, R. (2007). Removal efficiency of subsurface vertical flow constructed wetlands for different organic loads. Wat. Sci. \& Tech 56(3), 75-84.

43. Noorvee, A., Pöldvere, E. and Mander, Ü. (2005). The effect of a vertical flow bed on a hybrid constructed wetland system. Wat. Sci. \& Tech 51(9), 137-144.

44. Da Motta Marques, D. M. L., Leite, G. R. and Giovannini, S. G. T. (2001). Performance of two macrophyte species in experimental wetland receiving variable loads of anaerobically treated municipal wastewater. Wat. Sci. Tech., 44 (11/12), 311-317.
45. Maehlum, T. and Stålnacke, P. (1999). Removal efficiency of three cold climate constructed wetlands tyreating domestic wastewater: effects of temperature, seasons, loading rate and input concentrations. Wat. Sci. Tech., 40(3), 273-281.

46. Geller, G. (1997) Horizontal subsurface flow systems in the German speaking countries: summary of long term scientific and practical experiences; recommendations. Wat. Sci. Tech., 35(5), 157-166.

47. Reddy, G.B., Hunt, P.G., Phillips, R., Stone, K. and Grubbs, A. (2001). Treatment of swine wastewater in marsh-pond constructed wetlands. Wat. Sci. Tech., 44(11-12), 545-550.

48. Gearheart, R.A. (1992). Use of constructed wetlands to treat domestic wastewater, City of Arcata, Califonia, Wat. Sci. Tech., 26 (7-8), 1625-1637.

49. Chick, A.J. and Mitchell, D.S. (1995). A pilot study of vertical flow wetlands at Coffs habour, New South Wales, Australia. Wat. Sci. Tech., 32(3), 103-109.

50. Sun, G., Gray, K.R., Biddlestone, A.J., Allen, S.J. and Cooper, D.J. (2003). Effect of effluent recirculation on the performance of a reed bed system treating agricultural wastewater. Process Biochemistry, 39, 351-357.

51. Geary, P. M. and Moore, J. A. (1999). Suitability of a treatment wetland for dairt wastewater, Wat. Sci. Tech., 40 (3), 179-185.

52. Schonerklee, M., Koch, F., Perfler, R. and Laber, J. (1996). Tertiary treatment in a vertical flow reed bed system - a full-scale pilot plant for 200-600 p.e. In: Preprints Voll. of the 5th International Conference on Wetlands for Water pollution Control, Vienna, Sept. 15-19, 1996, $\mathrm{VI} / 2.1-2.8$

53. Soto, F., Garcia, M., de Luis, E. and Becares, E. (1998). Role of Scirpus lacustris in bacterial and nutrient removal from wastewaters. Wat. Sci. \& Tech 40(3), 241-247. 


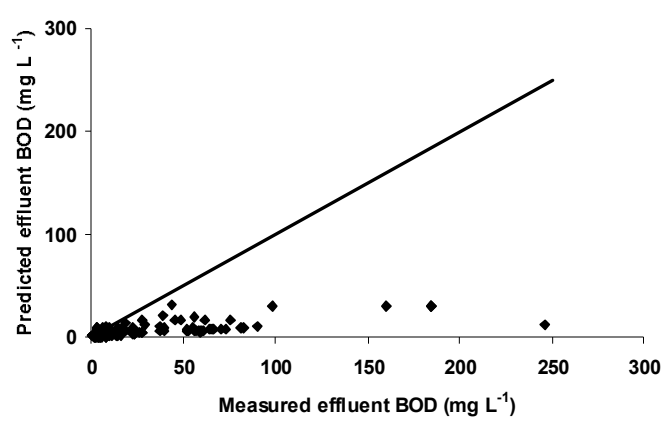

(a) Plot of measured versus predicted values of wetland effluent BOD Line represent the $100 \%$ removal. $\mathrm{R}^{2}=0.27, \mathrm{p}=0.000, \mathrm{n}=116$

\section{- SSF 口SF}

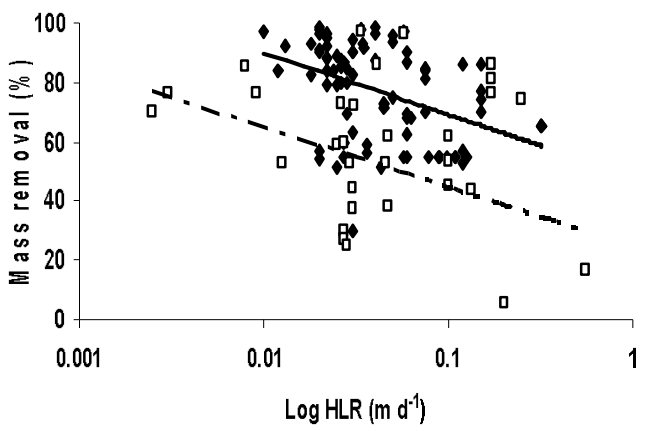

(c) The influence of HLR on BOD removal in SSF and SF wetland.

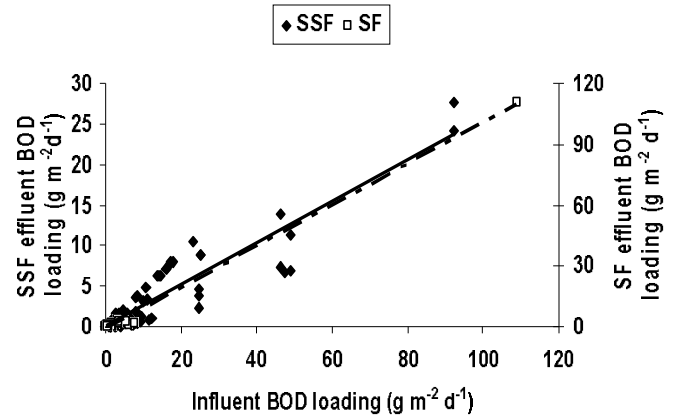

(b) Influent and effluent BOD loading relationships for SF and SSF wetlands.

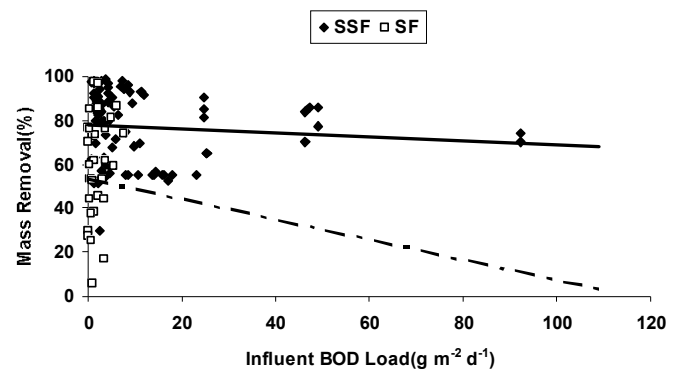

(d) The influence of influent loading on effluent BOD in SSF and SF wetland.

Fig 1. The influence of operational parameters (HLR \& influent loading) on subsurface flow -SSF and surface flow-SF wetland BOD removal. Bold and broken lines represent trend lines for SSF and SF respectively

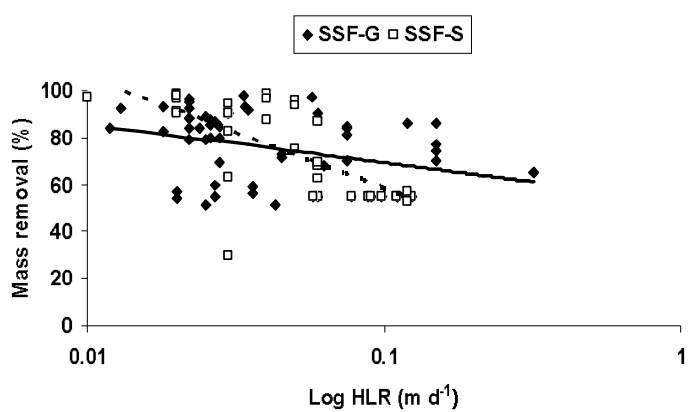

Fig 2a. Relationship between hydraulic loading rate and substrate type on the removal of organics (BOD) for SSF wetlands. Bold and broken lines represent trend lines for gravel and sand media respectively.

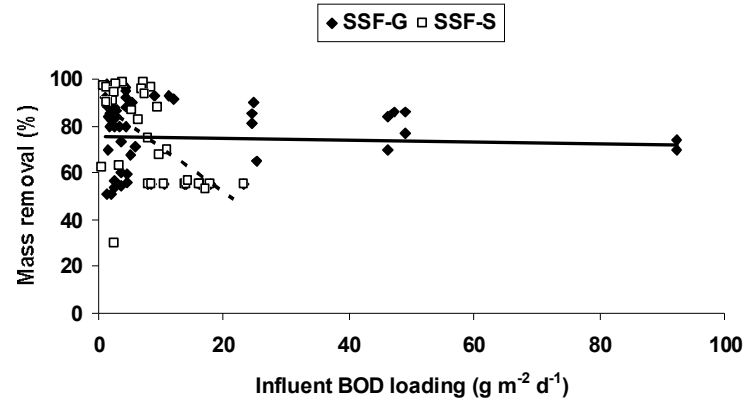

Fig 2b. Relationship between influent organic loading and substrate type on the removal of organics (BOD) for SSF wetlands. Bold and broken lines represent trend lines for gravel and sand media respectively. 


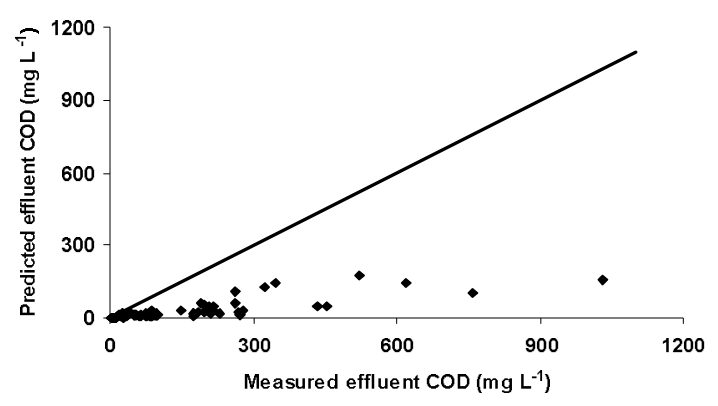

(a) Plot of measured versus predicted values of wetland effluent COD Line represent the $100 \%$ removal $\mathrm{R}^{2}=0.32, \mathrm{p}=0.000, \mathrm{n}=81$

$\bullet$ SSF ם SF

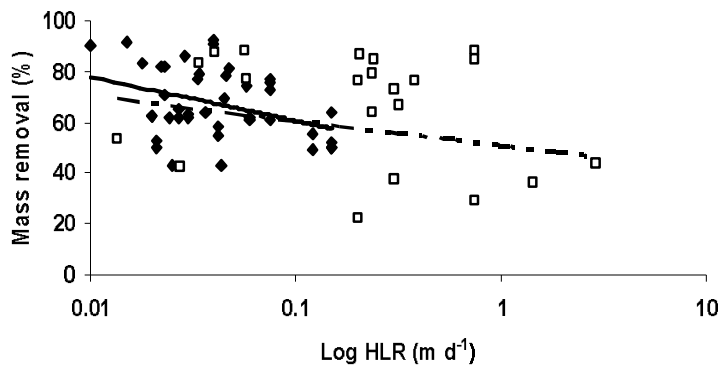

(c) The influence of HLR on COD removal in SSF and SF wetland.

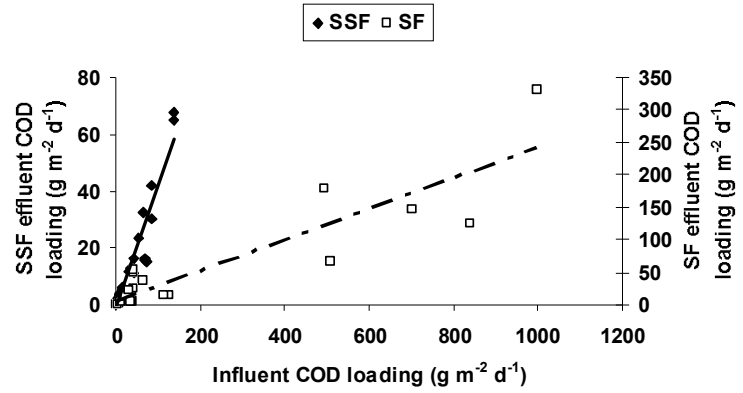

(b) Influent and effluent COD loading relationships for surface flow-SF and subsurface flow -SSF wetlands.

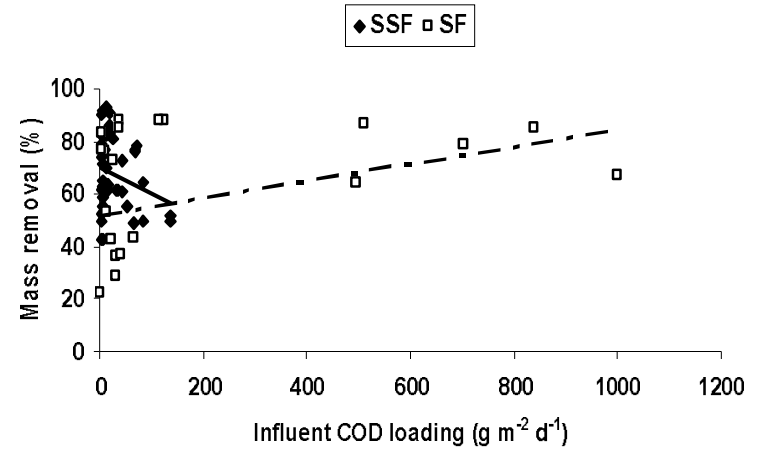

(d) The influence of influent loading on effluent COD in SSF and SF wetland.

Fig 3. The influence of operational parameters (HLR \& influent loading) on wetland COD removal

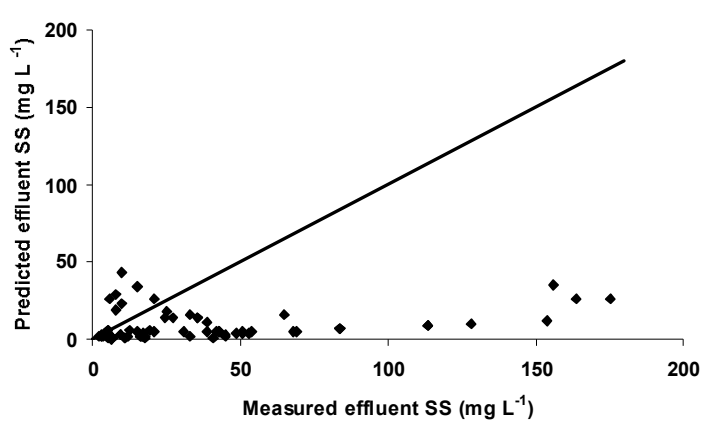

(a) Plot of measured versus predicted values of wetland effluent SS. Line represent the $100 \%$ removal $\mathrm{R}^{2}=0.24$, $\mathrm{p}=0.031, \mathrm{n}=71$

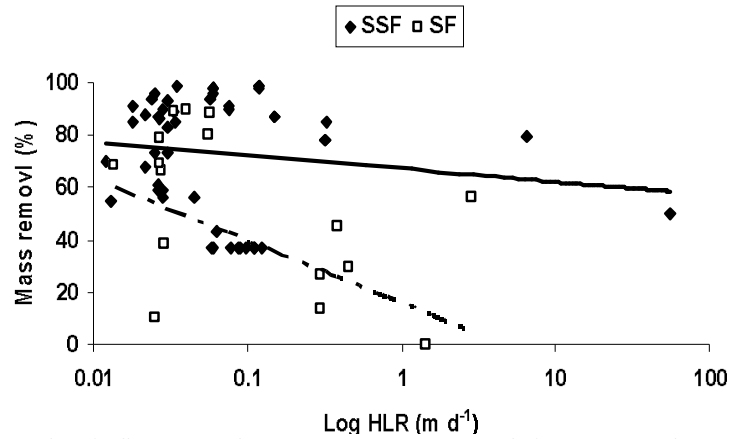

(c) The influence of HLR on SS removal in SSF and SF wetland.

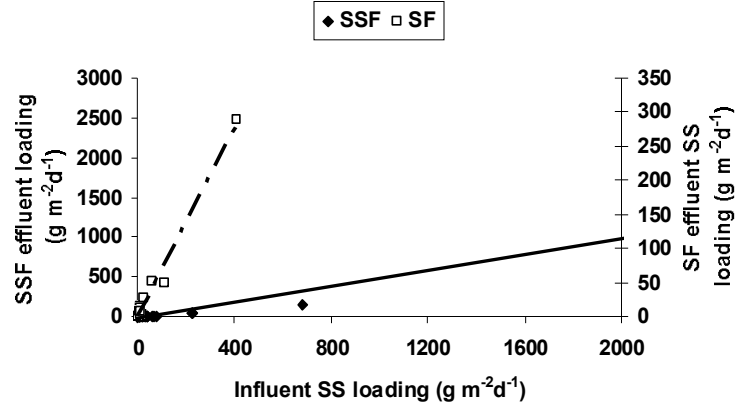

(b) Influent and effluent SS loading relationships for surface flow-SF and subsurface flow-SSF wetlands.

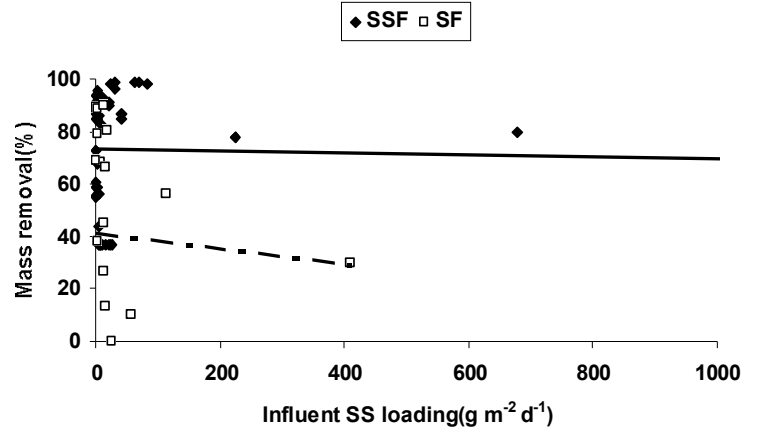

(d) The influence of influent loading on effluent SS in SSF and SF wetland.

Fig 4. The influence of operational parameters (HLR \& influent loading) on wetland SS removal 


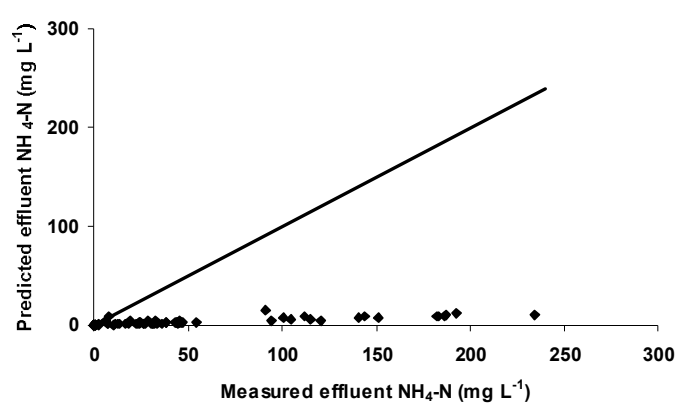

(a) Plot of measured versus predicted values of wetland effluent $\mathrm{NH}_{4}-\mathrm{N}$. Line represent the $100 \%$ removal $\mathrm{R}^{2}=0.09, \mathrm{p}=0.000, \mathrm{n}=74$

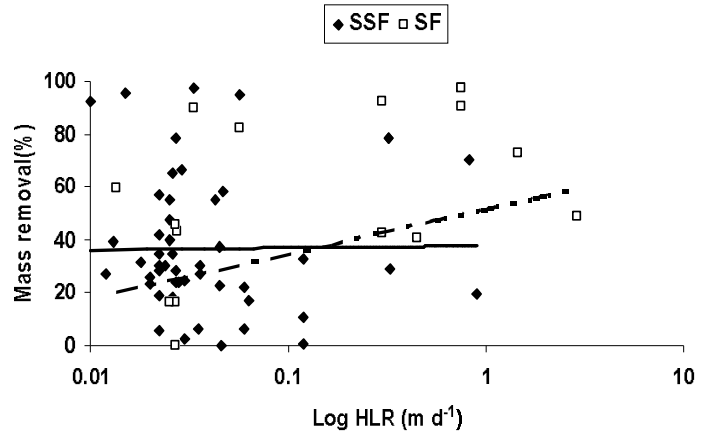

(c) The influence of HLR on $\mathrm{NH}_{4}-\mathrm{N}$ removal in SSF and SF wetland.

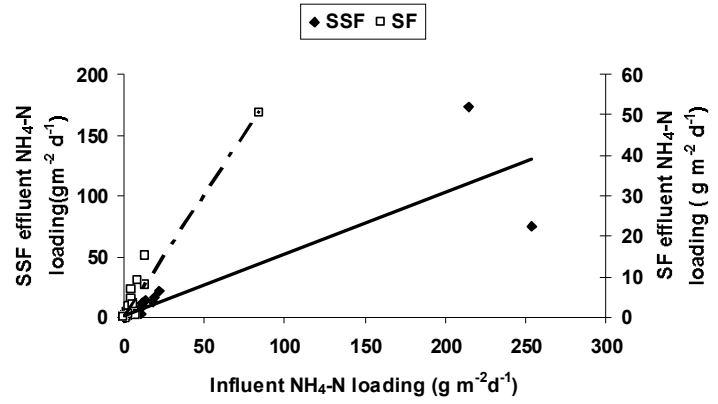

(b) Influent and effluent $\mathrm{NH}_{4}-\mathrm{N}$ loading relationships for surface flow-SF and subsurface flow -SSF wetlands.

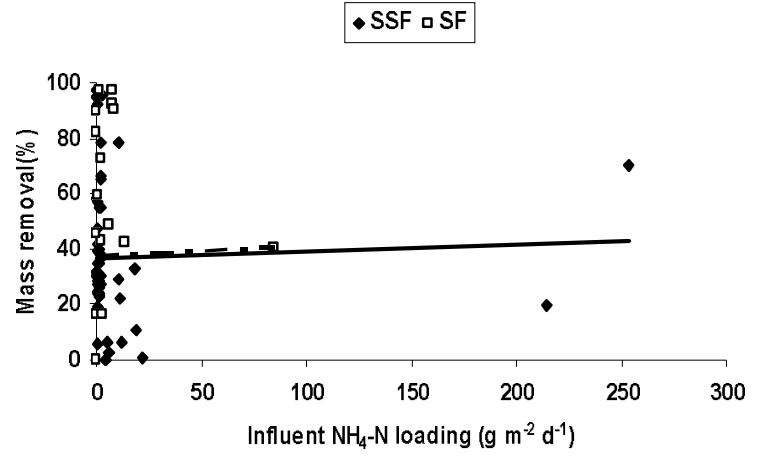

(d) The influence of influent loading on effluent $\mathrm{NH}_{4}-\mathrm{N}$ in SSF and SF wetland.

Fig 5. The influence of operational parameters (HLR \& influent loading) on wetland $\mathrm{NH}_{4}-\mathrm{N}$ removal. Bold and broken lines represent trend lines for SSF and SF respectively.

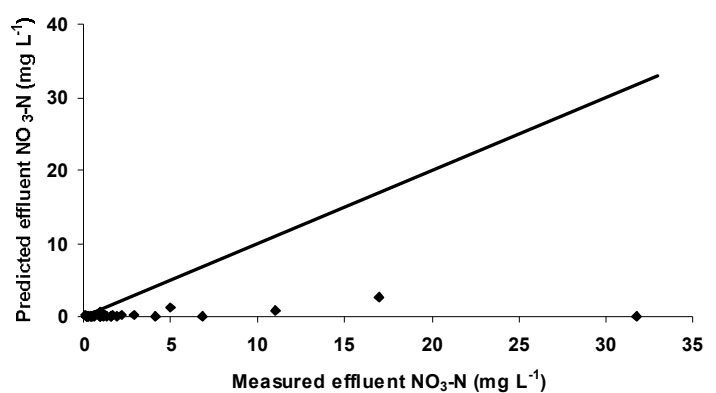

(a) Plot of measured versus predicted values of wetland effluent $\mathrm{NO}_{3}-\mathrm{N}$ Line represent the $100 \%$ removal $\mathrm{R}^{2}=0.08, \mathrm{p}=0.08, \mathrm{n}=33$

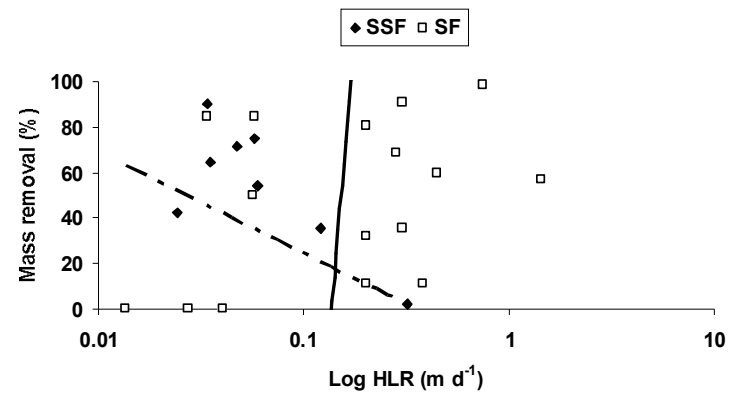

(c) The influence of HLR on $\mathrm{NO}_{3}-\mathrm{N}$ removal in SSF and SF wetland.

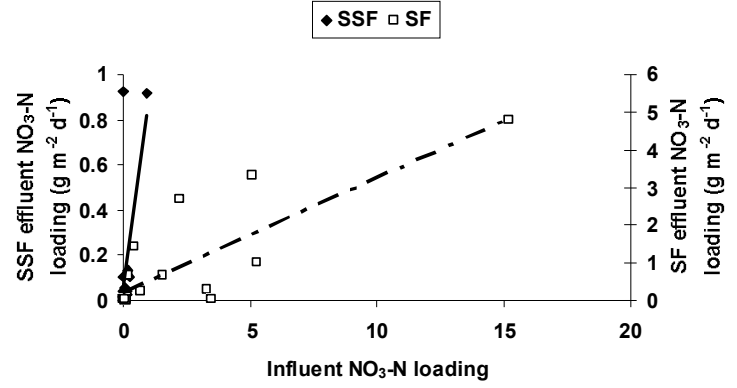

(b) Influent and effluent $\mathrm{NO}_{3}-\mathrm{N}$ loading relationships for surface flow-SF and subsurface flow -SSF wetlands.

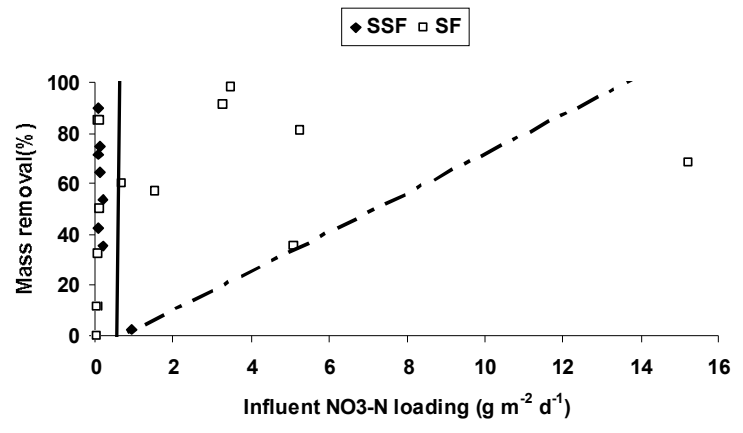

(d) The influence of influent loading on effluent $\mathrm{NO}_{3}-\mathrm{N}$ in $\mathrm{SF}$ and $\mathrm{SSF}$ wetland

Fig 6. The influence of operational parameters (HLR \& influent loading) on wetland $\mathrm{NO}_{3}-\mathrm{N}$ removal. Bold and broken lines represent trend lines for SSF and SF respectively. 


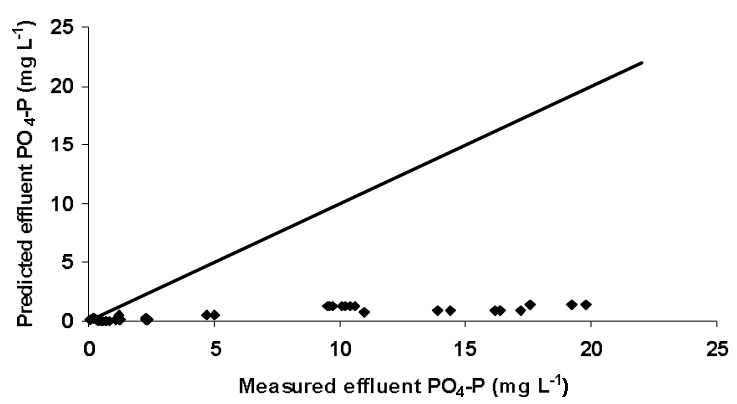

(a) Plot of measured versus predicted values of wetland effluent PO4-P Line represent the $100 \%$ removal $\mathrm{R}^{2}=0.16, \mathrm{p}=0.005, \mathrm{n}=38$

$$
\bullet \text { SSF }
$$

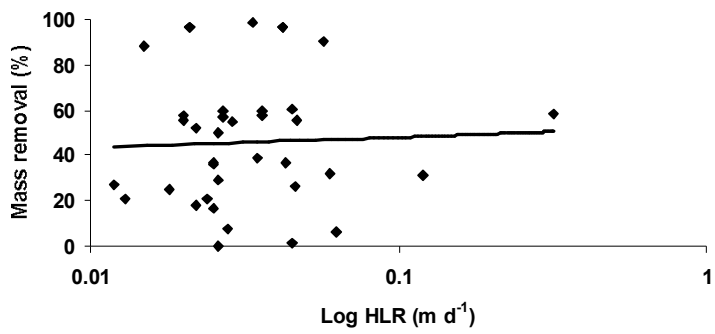

(c) The influence of $\mathrm{HLR}$ on $\mathrm{PO}_{4}-\mathrm{P}$ removal in SSF wetland.

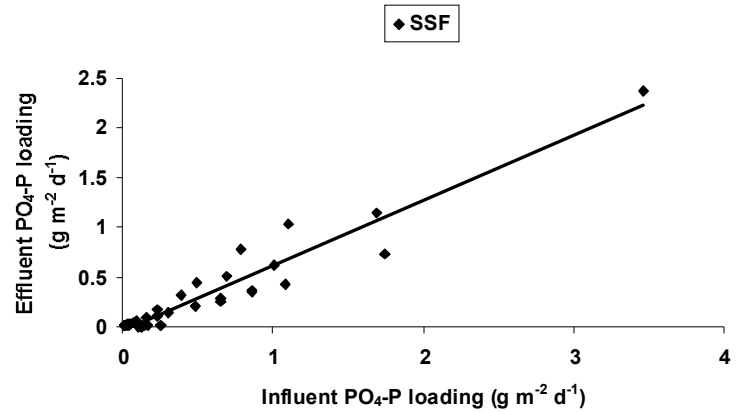

(b) Influent and effluent $\mathrm{PO}_{4}-\mathrm{P}$ loading relationships for $\mathrm{SSF}$ wetlands.

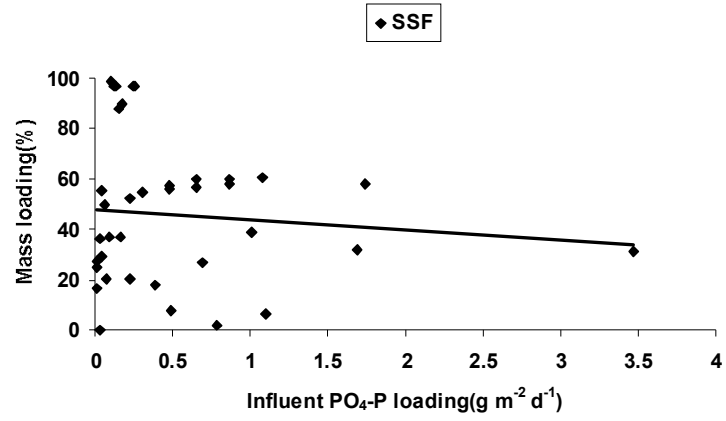

(d) The influence of influent loading on effluent $\mathrm{PO}_{4}-\mathrm{P}$ in SSF

Fig 7. The influence of operational parameters (HLR \& influent loading) on wetland $\mathrm{PO}_{4}-\mathrm{P}$ removal.

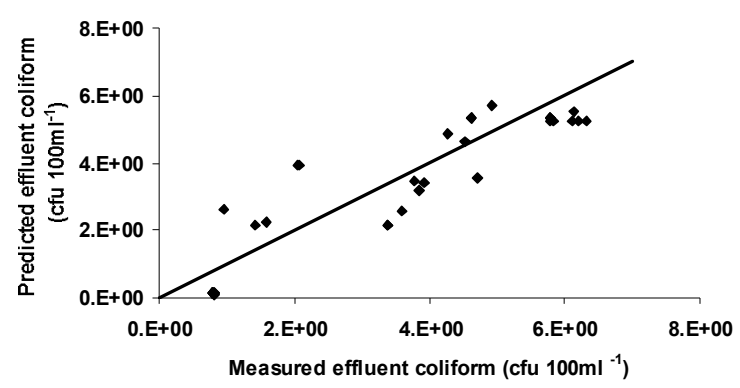

(a) Plot of measured versus predicted values of wetland effluent total coliforms. Line represent the $100 \%$ removal $\mathrm{R}^{2}=0.25, \mathrm{p}=0.000, \mathrm{n}=33$

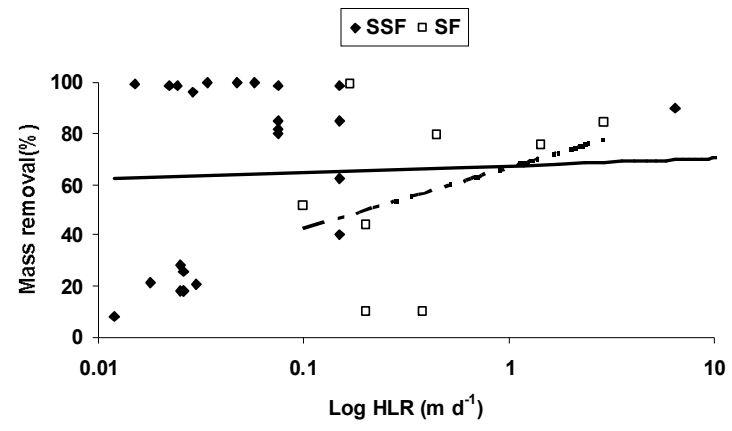

(c) The influence of HLR on total coliform removal in SSF and SF wetland.

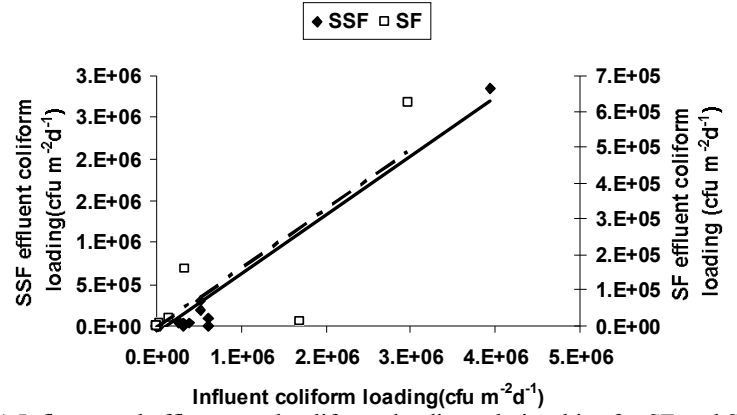

(b) Influent and effluent total coliforms loading relationships for SF and SSF wetlands.

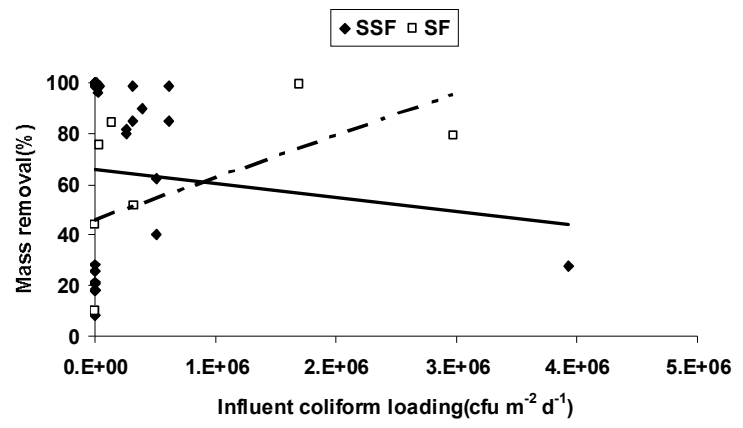

(d) The influence of influent loading on effluent total coliforms in SF and SSF

Fig 8. The influence of operational parameters (HLR \& influent loading) on wetland total coliform removal 